\title{
Kesepian pada Mahasiswa selama Pandemi COVID-19
}

\section{Loneliness among College Students during the COVID-19 Pandemic}

\author{
Martaria Rizky Rinaldi \\ Universitas Mercu Buana, Yogyakarta, Indonesia
}

\begin{abstract}
The present study aims to explore loneliness of college student during COVID-19 pandemic in Indonesia. A total of 236 respondents were participated in the study. Data collection was performed using UCLA Loneliness Scale version 3. Data were analyzed by using descriptive analysis, independent sampel t-test and ANOVA. The study found that more than half of the number of respondents were mild lonely $(66.95 \%)$, while the others were moderate lonely $(19.91 \%)$, and the rest were not lonely $(13.13 \%)$. The finding also showed that there is no significant difference in loneliness between men and women, as well as between respondents living in parents' houses and boarding or rented houses. Based on this study, it can be concluded that most participants experience loneliness in the mild level.
\end{abstract}

Keywords: Loneliness, students, COVID-19 pandemic

\begin{abstract}
Abstrak: Penelitian ini bertujuan untuk mendapatkan data empiris untuk mengetahui kesepian pada mahasiswa di masa pandemi COVID-19. Sampel penelitian yaitu 236 mahasiswa. Pengumpulan data dilakukan dengan menggunakan UCLA Loneliness Scale 3. Teknik analisis data yang digunakan yaitu analisis deskriptif dan uji beda dengan $t$-test dan ANOVA. Temuan dari penelitian ini yaitu sebesar $66,95 \%$ responden menunjukkan kesepian ringan, 19,91\% responden menunjukkan kesepian sedang, dan $13,13 \%$ responden menunjukkan tidak kesepian. Penelitian juga menunjukkan bahwa tidak ditemukan perbedaan kesepian yang signifikan antara laki-laki dan perempuan, maupun berdasarkan status tempat tinggal (rumah orang tua, indekos ataupun rumah kontrak). Berdasarkan penelitian ini dapat disimpulkan bahwa sebagian besar mahasiswa mengalami kesepian pada tingkat ringan.
\end{abstract}

Kata kunci: Kesepian, mahasiswa, pandemi COVID-19

Pandemi COVID-19 yang disebabkan oleh virus SARS-CoV-2 meluas dengan begitu cepatnya ke seluruh dunia, termasuk di Indonesia (WHO, 2020). Penyebaran COVID-19 di Indonesia juga telah meluas di semua Provinsi yang ada di Indonesia. Data dari Komite Penanganan COVID-19 dan Pemulihan Ekonomi Nasional (2021) hingga tanggal 17 Mei 2021 menunjukkan bahwa terdapat 1.748 .230 orang terkonfirmasi positif dengan 87.514 kasus aktif di 34 Provinsi di Indonesia.

Meluasnya COVID-19 dan banyaknya orang yang terkonfirmasi terinfeksi virus ini adalah disebabkan oleh mudahnya cara penyebaran virus corona. Penyebaran virus ini melalui mulut atau hidung atau mata yang terjadi ketika orang melakukan kontak

Korespondensi tentang artikel ini dapat dialamatkan kepada Martaria Rizky Rinaldi melalui email: martariarizky@mercubuana-yogya.ac.id 
langsung atau dekat dengan jarak kurang dari 1 meter dengan orang yang terinfeksi (WHO, 2020b).

Cara penularan yang berisiko besar ketika melakukan kontak yang dekat menjadi alasan diberlakukannya berbagai kebijakan dan peraturan terutama pemakaian masker dan pembatasan jarak sosial atau social distancing guna menurunkan risiko penularan dengan kontak langsung. Pada bidang pendidikan, telah dikeluarkan kebijakan pemerintah mengenai pembelajaran online atau dalam jaringan (daring) dan Kerja dari Rumah atau Work From Home (WFH) untuk mencegah penyebaran COVID-19 (Kemendikbud RI, 2020). Kebijakan ini membuat sistem pembelajaran yang dulunya tatap muka kini berubah menjadi online atau daring (Arora \& Srinivasan, 2020). Kondisi pembelajaran secara daring ini mempengaruhi interaksi mahasiswa. Terjadi penurunan tingkat komunikasi antara mahasiswa dengan dosen (Alawamleh et al, 2020), dan menurunnya interaksi sosial selama pembatasan jarak sosial (Son et al., 2020).

Pembatasan fisik yang diberlakukan membuat penurunan interaksi sosial yang dapat berdampak pada meningkatnya rasa kesepian. Kesepian merupakan situasi yang secara subjektif dirasakan individu terkait dengan perasaan kekurangan dalam hal kuantitas dan kualitas hubungan (de JongGierveld, 1987). Kesepian dapat terjadi ketika jumlah hubungan yang dimiliki lebih kecil dibandingkan dari yang diinginkan serta situasi yang menunjukkan keitiman yang diharapkan belum terwujud (de JongGierveld et al., 2006).

Kondisi pandemi dapat memperparah kesepian yang dialami oleh individu. Hal ini dikarenakan interaksi sosial yang terbatas merupakan faktor risiko dari kesepian dewasa muda (Victor, 2011). Selain itu, usia fase remaja akhir dan awal dewasa muda merupakan fase yang berisiko tinggi untuk mengalami kesepian (Groarke et al., 2020; Li \& Wang, 2020; Rubenstrein \& Shaver, 1982). Hal ini dikarenakan pada fase ini individu menghadapi tugas perkembangan untuk mendapatkan kedekatan atau intimasi dan menghindari isolasi sosial. Penelitian menunjukkan bahwa usia 19 tahun merupakan usia yang rawan mengalami kesepian (Shovestul et al., 2020).

Kesepian dapat didefinisikan sebagai pengalaman tidak menyenangkan yang terjadi ketika jaringan seseorang dalam hubungan sosial secara signifikan lebih rendah secara kualitas maupun kuantitas (Margalit, 2010). Hal ini berarti terjadi ketimpangan antara kontak sosial yang diinginkan dengan kondisi aktual kontak sosial tersebut hingga membuat individu mengalami perasaan kesepian.

Pada dasarnya, kesepian sering ditandai dengan penilaian pribadi terkait dengan isolasi sosial yang bersifat subjektif, bukan secara objektif (Hawkley \& Cacioppo, 2010). Individu mungkin memiliki banyak kontak sosial dan banyak teman, namun merasa kesepian, sedangkan individu lain mungkin memiliki sedikit hubungan yang dekat namun merasa puas dalam hubungan yang terjalin.

Kesepian terjadi lebih bergantung pada penilaian pribadi individu dalam hubungannya daripada hanya pada jumlah teman yang dimiliki (Heinrich \& Gullone, 2006). Kesepian terjadi ketika seseorang tidak bahagia dengan keadaan hubungan yang dimiliki saat ini kemudian mengalami perasaan negatif seperti kesedihan atau keputusasaan (Buchholz \& Catton, 1999). Kesepian juga berkaitan dengan kondisi kesejahteraan psikologis dan emosional serta distres psikologis (Franssen et al., 2020)

Kesepian berkorelasi dengan beberapa gangguan psikologis, terutama gangguan mood, perilaku menyakiti diri sendiri dan bunuh diri serta dapat menurunkan kondisi kesehatan mental saat ini (Holmes et al., 2020). Kesepian juga berhubungan dengan buruknya kondisi fisik dan mental serta meningkatkan risiko kematian (Holt-Lunstad et al., 2015). Jika kesepian dibiarkan dan tanpa penanganan maka akan berdampak negatif. Oleh karena itu, diperlukan data empiris 
untuk mengetahui tingkat kesepian agar nantinya dapat diberikan penanganan yang tepat.

Pada konteks nonpandemi, isolasi geografis, hidup sendiri, dan kurangnya keterikatan sosial memprediksi kesepian pada populasi orang dewasa dan lansia (Beutel dkk., 2017). Dalam konteks pandemi, terjadi isolasi sosial yang masif sebagai upaya untuk mencegah atau mengurangi penyebaran virus, sehingga isolasi geografis tidak hanya terjadi pada lansia, namun termasuk terjadi pada mahasiswa. Kesepian pada mahasiswa ditemukan mempengaruhi kinerja akademiknya (Bek, 2017). Hal ini dikarenakan mahasiswa yang yang merasa kesepian dan mengisolasi diri cenderung tidak berpartisipasi dalam kegiatan akademik. Selain itu, kesepian juga ditemukan berkaitan dengan stres akademik (Stoliker \& Lafreniere, 2015).

Penelitian terdahulu tentang kesepian dalam konteks masa pandemi pada individu dengan periode perkembangan tertentu telah dilakukan. Akan tetapi, belum banyak penelitian yang secara khuus mengungkap mengenai kesepian pada mahasiswa di masa pandemi COVID-19 ini. Sagita dan Hermawan (2020) meneliti 300 remaja di Indonesia dan menunjukkan bahwa $43 \%$ dari responden menunjukkan kesepian pada kategori cukup tinggi, $10 \%$ pada kategori tinggi, dan $1,7 \%$ pada kategori sangat tinggi. Penelitian terkait kesepian pada usia dewasa muda dilatarbelakangi oleh masa pandemi juga telah dilakukan dengan hasil yang menunjukkan tingkat kesepian yang cukup tinggi (Groarke et al., 2020; Li \& Wang, 2020.

Penelitian kali ini dikhususkan untuk memahami kesepian pada responden mahasiswa. Mahasiswa merupakan kelompok yang rentan mengalami dampak mental dari pandemi COVID-19 dikarenakan tantangan yang dihadapi di perguruan tinggi. Hal ini terjadi karena munculnya permasalahan baru karena pandemi, seperti perubahan sistem pembelajaran secara daring, wisuda yang menjadi tertunda, berkurangnya atau bahkan hilangkan kesempatan untuk bekerja ataupun magang (Aucejo et al., 2020; Seidel et al., 2020)

Faktor protektif dari kesepian yaitu terkait dengan variabel-variabel sosial (Bu et al., 2020; Li \& Wang, 2020). Kedekatan dan kualitas hubungan diperlukan untuk melindungi diri dari kesepian. Selama masa pandemi, mahasiswa ada yang memutuskan untuk kembali pulang ke rumah orang tua masing-masing, namun ada pula yang memilih untuk tetap tinggal di perantauan, baik indekos maupun di rumah kontrakan. Ketika berada jauh dengan keluarga, kedekatan dan kualitas hubungan mahasiswa dengan keluarganya menjadi berkurang. Kuantitas dan kualitas interaksi sosial dengan sesama teman mahasiswa juga menjadi berkurang karena banyaknya mahasiswa yang pulang kampung akibat kebijakan perguruan tinggi untuk menerapkan pembelajaran daring sebagai upaya mencegah penyebaran COVID19. Untuk memastikan hal tersebut, maka penting untuk mendapatkan data empiris mengenai perbedaan tempat tinggal terhadap kesepian pada mahasiswa.

Selain itu, meneliti faktor jenis kelamin dalam variabel kesepian pada konteks mahasiswa juga penting. Beberapa penelitian terdahulu telah menguji keterkaitan antara kesepian dengan jenis kelamin. Penelitian Wiseman et al. (1995) menyatakan bahwa mahasiswa Israel laki-laki merasakan kesepian yang lebih tinggi daripada perempuan. Temuan ini berbeda dengan temuan Wedaloka dan Turnip (2019) yang menunjukkan bahwa perempuan lebih rentan mengalami kesepian dibandingkan laki-laki. Namun, hasil penelitian Ningrumsari dan Sawitri (2018) justru menunjukkan bahwa tidak terdapat perbedaan kesepian antara perempuan dan laki-laki. Ketidaksesuaian dari beberapa hasil penelitian sebelumnya mengenai keterkaitan kesepian dan jenis kelamin membuat penelitian lanjutan untuk memastikan isu ini menjadi penting untuk dilakukan.

Berdasarkan permasalahan tersebut, penelitian ini bertujuan untuk mengetahui 
bagaimana gambaran kesepian pada mahasiswa pada masa pandemi COVID-19 di Indonesia. Hipotesis yang diajukan yaitu: 1) Terdapat tingkat kesepian pada mahasiswa pada masa pandemi COVID-19 di Indonesia; 2) Terdapat perbedaan jenis kelamin terhadap kesepian pada mahasiswa di masa pandemi COVID-19; 3) Ada perbedaan tingkat kesepian jika ditinjau dari lokasi tempat tinggal mahasiswa.

\section{Metode}

Penelitian ini menggunakan metode kuantitatif dengan desain survei berjenis cross sectional.

\section{Sampel}

Kriteria partisipan penelitian ini adalah mahasiswa aktif di perguruan tinggi di Indonesia. Total partisipan penelitian ini berjumlah 236 yang didapatkan dari berbagai provinsi di Indonesia. Penelitian ini mengumpulkan data secara online. Karena itu, teknik pengambilan sampel menggunakan convenient sampling karena responden otomatis terseleksi ketika menerima link kuesioner yang tersebar. Semua mahasiswa Indonesia yang dapat mengakses internet, memahami Bahasa Indonesia, dan bersedia berpartisipasi bisa terlibat dalam penelitian ini.

\section{Pengumpulan Data}

Pengumpulan data dalam penelitian ini menggunakan UCLA Loneliness Scale version 3 yang dikembangkan oleh Russell (1996). Skala kesepian ini telah terbukti memiliki reliabilitas yang tinggi dengan internal konsistensi (koefisien alpha dalam rentang 0,89 hingga 0,94) dan reliabilitas test-retest dalam periode satu tahun yaitu $\mathrm{r}$ $=0,73$. Validitas konvergen dari skala ini juga menunjukkan korelasi yang signifikan dengan alat ukur lain dalam mengukur kesepian (Russell, 1996).

Kuesioner online disebarkan menggu- nakan google form. Pada kuesioner terdapat bagian persetujuan, sehingga hanya partisipan yang menyetujui informed consent yang mengisi kuesioner. Tautan kuesioner dikirimkan melalui media sosial WhatsApp dan Instagram. Partisipan juga didorong untuk membagikan tautan ke orang lain sebanyak mungkin, dengan demikian, tautan disebarkan secara meluas. Ketika partisipan menerima dan menekan tautan maka ia akan terarah pada halaman yang berisi informasi penelitian dan informed consent. Setelah partisipan menyetujui, ia diarahkan pada isian data demografis dan skala kesepian.

Pengumpulan data dimulai dari tanggal 25 hingga 31 Oktober 2020. Setelah data terkumpul, selanjutnya dilakukan pemeriksaan untuk melihat kelengkapan data. Jika data tidak lengkap atau terdapat respon yang kurang jelas, maka data dieliminasi. Jumlah pengisi data yang didapatkan yaitu 245 dan dieliminasi 9 orang.

\section{Analisis Data}

Data hasil penelitian dianalisis secara deskriptif untuk mengetahui tingkat kesepian pada mahasiswa. Sebelumnya dilakukan uji prasyarat untuk melihat homogenitas dan linearitas dari variabel. Selanjutnya untuk menjawab hipotesis penelitian kedua dan ketiga, digunakan teknik analisis statistik dengan bantuan IBM SPSS 22.0 for Windows dengan uji beda $t$-test untuk melihat perbedaan pada kelompok laki-laki dan perempuan. Analisis dengan menggunakan ANOVA digunakan untuk melihat perbedaan lokasi tempat tinggal, yaitu indekos, kontrakan, dan rumah.

\section{Hasil}

Berdasarkan hasil penelitian seperti yang ditunjukkan pada Tabel 1, diperoleh skor rata-rata kesepian pada mahasiswa yaitu 42, dengan standar deviasi (SD) 7,4. Nilai maksimal kesepian yaitu 60 dan nilai minimalnya adalah 22 . 
Tabel 1. Data Deskriptif Kesepian

\begin{tabular}{ccccc}
\hline & Mean & SD & Max & Min \\
\hline Kesepian & 43 & 7,4 & 60 & 22 \\
\hline
\end{tabular}

Berdasarkan distribusi kategori tingkat kesepiannya, hasil penelitian ini menunjukkan bahwa terdapat $66,95 \%$ mahasiswa yang mengalami kesepian ringan, dan $19,91 \%$ kesepian sedang, serta $13,13 \%$ tergolong tidak mengalami kesepian dan tidak ada yang mengalami kesepian tingkat berat. Data distribusi ini dapat dilihat pada Tabel 2.

Tabel 2. Distribusi Frekuensi dan Persentase Kesepian

\begin{tabular}{cccc}
\hline $\begin{array}{c}\text { Interval } \\
\text { skor }\end{array}$ & Kategori & Frekuensi & $\%$ \\
\hline $20-34$ & $\begin{array}{c}\text { Tidak } \\
\text { kesepian }\end{array}$ & 31 & 13.13 \\
$35-49$ & $\begin{array}{c}\text { Kesepian } \\
\text { ringan }\end{array}$ & 158 & 66,95 \\
$50-64$ & $\begin{array}{c}\text { Kesepian } \\
\text { sedang }\end{array}$ & 47 & 19,91 \\
$65-80$ & $\begin{array}{c}\text { Kesepian } \\
\text { Berat }\end{array}$ & 0 & 0 \\
\hline
\end{tabular}

Data selanjutnya terkait demografis dari partisipan antara lain jenis kelamin, status tempat tinggal, dan asal provinsi. Dari 236 partisipan, 15 orang berjenis kelamin laki-laki dan 221 perempuan. Berdasarkan status tempat tinggal, 207 tinggal di rumah dengan orang tua, 26 indekos, dan 3 orang tinggal di rumah kontrak.

\section{Uji Asumsi}

Uji normalitas jenis kelamin dengan kesepian menunjukkan $\mathrm{K}-\mathrm{S} \mathrm{Z}=0,236, \mathrm{p}=$ $0,00(\mathrm{p}<0,050)$, dengan demikian disimpulkan bahwa data tidak berdistribusi normal. Uji normalitas status tempat tinggal dengan kesepian menunjukkan K-S Z =0,078, $\mathrm{p}=$ $0,002(\mathrm{p}<0,050)$, dengan demikian disimpulkan bahwa data tidak berdistribusi normal. Menurut Azwar (2017), tidak perlu terlalu mengkhawatirkan uji normalitas ini sepanjang memiliki banyak subjek bagi masing-masing variabel. Priyatno (2010) mengungkapkan bahwa data yang banyaknya lebih dari 30 maka dapat dikatakan berdistribusi normal dan biasa disebut sampel besar. Penelitian ini menggunakan subjek sebanyak 236.

Tabel 2. Data Demografi Partisipan

\begin{tabular}{|c|c|c|}
\hline Demografi & $\mathrm{N}$ & $\%$ \\
\hline \multicolumn{3}{|c|}{ Jenis Kelamin } \\
\hline Laki-laki & 15 & 6,4 \\
\hline Perempuan & 221 & 93,6 \\
\hline \multicolumn{3}{|c|}{ Status Tempat Tinggal } \\
\hline $\begin{array}{l}\text { Di rumah bersama } \\
\text { keluarga }\end{array}$ & 207 & 87,7 \\
\hline Di kos & 26 & 11 \\
\hline Di kontrakan & 3 & 1,3 \\
\hline \multicolumn{3}{|c|}{ Provinsi tempat tinggal } \\
\hline Aceh & 1 & 0,4 \\
\hline Banten & 8 & 3,4 \\
\hline DI Yogyakarta & 33 & 14 \\
\hline DKI Jakarta & 16 & 6,8 \\
\hline Gorontalo & 2 & 0,8 \\
\hline Jawa Barat & 40 & 16,9 \\
\hline Jawa Tengah & 45 & 19,1 \\
\hline Jawa Timur & 25 & 10,6 \\
\hline Kalimantan Tengah & 3 & 1,3 \\
\hline Kalimantan Timur & 2 & 0,8 \\
\hline Kepulauan Riau & 4 & 1,7 \\
\hline Lampung & 21 & 8,9 \\
\hline Nusa Tenggara Barat & 4 & 1,7 \\
\hline Nusa Tenggara Timur & 1 & 0,4 \\
\hline Sulawesi Selatan & 12 & 5,1 \\
\hline Sulawesi Tengah & 22 & 9,3 \\
\hline Sumatera Barat & 3 & 1,3 \\
\hline Sumatera Utara & 10 & 4,2 \\
\hline Sumatera Selatan & 4 & 1,7 \\
\hline
\end{tabular}

Uji linearitas jenis kelamin dengan kesepian menunjukkan $\mathrm{F}=0.174, \mathrm{p}=0.677$ $(\mathrm{p} \geq 0.050)$, hal ini berarti hubungan antara kedua variabel merupakan hubungan yang tidak linier. Selanjutnya, uji linearitas status tempat tinggal dengan kesepian menunjukkan $F=0.319, p=0.573(p \geq 0.050)$ hal ini berarti hubungan antara kedua variabel merupakan hubungan yang tidak linier. 


\section{Uji Hipotesis}

\section{Perbedaan jenis kelamin dalam kesepian}

Uji hipotesis menggunakan $t$-test menunjukkan $\mathrm{F}=0,707$ dengan $\mathrm{p}=0.401(\mathrm{p}>$ 0.05), maka dapat diartikan bahwa varians data antara kelompok laki-laki dan perempuan adalah sama. Hasil t-test juga menunjukkan nilai $\mathrm{t}=0,418$, dan $\mathrm{p}=0,677$ ( $\mathrm{p}$ $>0,05)$, maka dapat disimpulkan bahwa tidak terdapat perbedaan antara kesepian laki-laki dan kesepian pada perempuan. Rerata kesepian berdasarkan jenis kelamin adalah sebagai berikut. Rata-rata kesepian pada perempuan yaitu 43,0995 sedangkan rata-rata kesepian laki-laki adalah 42,2667. Hasil ini menunjukkan bahwa tidak ada perbedaan kesepian yang cukup berarti pada perempuan dan laki-laki.

\section{Perbedaan status tempat tinggal dalam kesepian}

Uji hipotesis dilakukan dengan menggunakan ANOVA. Dari hasil analisis diketahui bahwa $\mathrm{F}=0,362$ dengan $\mathrm{p}=0.697(\mathrm{p}$ $>0.05$ ), maka menunjukkan bahwa tidak terdapat perbedaan kesepian ditinjau dari status tempat tinggal. Rata-rata kesepian yang tinggal di rumah dengan orang tua yaitu 42,9807, tinggal indekos yaitu 43,1538 , dan yang tinggal di rumah kontrak yaitu 46,6667. Data tersebut menunjukkan bahwa tidak ada perbedaan yang berarti pada kesepian para subjek berdasarkan tempat tinggal.

\section{Pembahasan}

Hasil penelitian ini menunjukkan bahwa sebagian besar mahasiswa mengalami kesepian mulai dari ringan hingga sedang. Kesepian yang dialami para partisipan tersebut tidak dapat dilepaskan dari adanya perubahan yang signifikan dalam kehidupan kampus dan penurunan interaksi sosial sebagai akibat pembatasan sosial masa pandemi (Banerjee \& Rai, 2020).
Hasil ini berbeda dengan penelitian di Inggris selama masa pandemi yang menunjukkan hanya sekitar $27,4 \%$ dari seluruh responden yang diteliti melaporkan mengalami kesepian, sementara 72,6\% responden melaporkan tidak merasa kesepian (Groarke et al., 2020). Perbedaan hasil ini mengindikasikan adanya faktor perbedaan budaya dalam tingkat kesepian pada mahasiswa (Bauer \& Rokach, 2012). Perbedaan budaya juga tercermin misalnya dari hasil penelitian Bauer dan Rokach (2012) yang menemukan bahwa mahasiswa dari negara Kanada dan Cekoslowakia memiliki perbedaan dalam tingkat kesepian. Meskipun demikian, pada penelitian dengan populasi yang lebih besar di Inggris (15.530 orang), hasil menunjukkan bahwa lebih dari sepertiga responden melaporkan bahwa mereka mengalami kesepian (Li \& Wang, 2020). Hal ini menunjukkan bahwa kesepian memang dialami oleh banyak orang selama masa pandemi secara lintas negara dan budaya.

Penelitian ini menunjukkan bahwa tidak ada perbedaan jenis kelamin dalam tingkat kesepian pada masa pandemi. Beberapa penelitian sebelumnya terkait perbedaan jenis kelamin dalam kesepian menunjukkan hasil yang tidak konsisten. Dalam studi menggunakan fokus grup pada mahasiswa yang mencari bantuan melalui konseling terkait kondisinya, ditemukan bahwa laki-laki lebih kesepian dibanding dengan perempuan (Wiseman et al., 1995). Namun, berdasarkan hasil metaanalisis Pinquart dan Sorensen (2001) terhadap 102 penelitian, ditemukan bahwa perempuan menunjukkan tingkat kesepian yang lebih tinggi daripada laki-laki. Penelitian tentang kesepian pada masa pandemi COVID-19 juga menunjukkan bahwa kesepian lebih banyak terjadi pada perempuan (Li \& Wang, 2020; Bu et al., 2020). Namun, hasil penelitian kali ini mengkonfirmasi penelitian terdahulu yang menyimpulkan bahwa tidak ada perbedaan kesepian pada laki-laki dan perempuan pada masa pandemi.

Perempuan dan laki-laki cenderung merasakan kesepian yang sama. Ketika di- 
temukan adanya perbedaan gender dalam kesepian, perbedaan tersebut lebih mencerminkan pada sejauh mana perempuan dan laki-laki bersedia melaporkan rasa kesepian yang dialami (Barreto, 2021). Laki-laki lebih enggan untuk mengakui perasaan kesepiannya karena akan lebih distigmatisasi daripada perempuan yang mengungkapkan perasaan yang sama (Borys \& Perlman, 1985). Dengan demikian, tidak adanya perbedaan tingkat kesepian pada laki-laki dan perempuan yang menjadi hasil penelitian kali ini mengindikasikan bahwa seluruh partisipan melaporkan kondisi kesepiannya nya secara lebih terbuka.

Selain itu, adanya perbedaan gender dalam kesepian seringkali dipengaruhi oleh faktor lain. Penelitian Aartsen \& Jylha (2011) menunjukkan bahwa ketika faktor lain seperti status pernikahan, kesehatan, usia, dan pengaturan tempat tinggal dikontrol maka tidak ada perbedaan gender yang signifikan pada pengalaman kesepian. Pada penelitian ini, terdapat kesamaan dalam beberapa faktor tersebut. Penelitian ini dilakukan pada mahasiswa yang seluruhnya berstatus belum menikah, dalam kondisi kesehatan yang baik, rentang usia yang tidak terlalu jauh, dan status tempat tinggal yang mayoritas bersama keluarga di rumah $(87,7 \%)$.

Hasil penelitian ini menunjukkan tidak ada perbedaan rerata kesepian ketika ditinjau dari faktor status tempat tinggal, yaitu rumah orang tua, indekos, atau rumah kontrak. Berdasarkan penelitian Kearns et al. (2015), ditemukan bahwa individu yang menyadari bahwa ada lebih banyak orang di sekitarnya, merasakan kesepian yang lebih rendah. Hal ini berarti dimungkinkan tidak ada perbedaan persepsi dalam pengenalan orang sekitar pada partisipan penelitian ini karena mayoritas bertempat tinggal bersama keluarga. Tidak adanya perbedaan kesepian ditinjau dari asal provinsi dalam penelitian ini juga dimungkinkan karena adanya kesamaan situasi saat mereka tinggal di rumah bersama keluarga, yaitu situasi pandemi. Kondisi pandemi mem- buat setiap orang melakukan isolasi diri, sehingga di manapun tempat tinggalnya, individu lebih banyak menghabiskan waktu bersama orang dekat di tempat tinggalnya. Karena itu, pengalaman isolasi diri bersama keluarga dapat menjelaskan kesamaan pengalaman kesepian pada mayoritas responden penelitian ini (Groarke et al. 2020).

\section{Simpulan}

Hasil penelitian ini menunjukkan bahwa sebagain besar mahasiswa mengalami kesepian mulai dari tingkat ringan hingga sedang. Selain itu tidak ada perbedaan jenis kelamin dalam tingkat kesepian mahasiswa dan tidak ada perbedaan dalam tingkat kesepian mahasiswa jika ditinjau dari status tempat tinggal mereka.

\section{Saran}

Keterbatasan dari penelitian ini adalah belum menjangkau populasi dari daerahdaerah di seluruh Indonesia. Respon dari penelitian berasal dari 19 provinsi dari 34 provinsi yang ada di Indonesia, sehingga untuk penelitian selanjutnya disarankan untuk dapat lebih menjangkau responden dari semua provinsi di Indonesia agar dapat lebih dapat memahami kesepian sebagai dampak dari pandemi pada mahasiswa di Indonesia. Selain itu, variabel kesepian perlu diuji kaitannya dengan berbagai faktor penyebabnya terutama dalam konteks pandemi serta perlu diteliti dengan berbagai variabel psikologis lainnya.

Bagi perguruan tinggi, hendaknya dapat menciptakan program pencegahan dan penanganan kesepian untuk mahasiswanya misalnya dengan memberikan psikoedukasi dan berbagai pelatihan pengelolaan emosi, serta layanan konseling secara online. Hasil penelitian ini menunjukkan tidak ada perbedaan jenis kelamin dalam tingkat kesepian mahasiswa. Hal ini berarti dalam memberikan penanganan terkait dengan kesepian tidak diperlukan pembedaan antara laki-laki dan perempuan. Hasil penelitian ini juga 
menunjukkan tidak ada perbedaan tingkat kesepian jika ditinjau dari status tempat tinggal. Dengan demikian, penanganan kesepian pada mahasiswa diarahkan kepada semua tanpa memperhatikan tempat tinggal mahasiswa. Kegiatan penanganan dan konsultasi secara online dapat dilakukan untuk mahasiswa dari berbagai lokasi tempat tinggal mereka.

\section{Daftar Pustaka}

Aartsen, M., \& Jylha, M. (2011). Onset of loneliness in older adults: Results of a 28 year prospective study. European Journal of Ageing, 8(1), 31-38. https://doi.org/10.1007/s10433-0110175-7.

Alawamleh, M. \& Al-Twait, (2020). The effect of online learning on communication between instructors and students during Covid-19 pandemic. Asian Education and Development Studies. 9(4), 1-21 https://doi.org/10.1108/AEDS-062020-0131

Arora, A.K. \& Srinivasan, R. (2020). Impact of Pandemic Covid19 on the Teaching-Learning process: A Study of Higher Education Teachers. Prabandhan, 13(4), 43-56. http://doi.org/10.17010/pijom\%2F20 20\%2Fv13i4\%2F151825

Aucejo, E. M., French, J. F., Araya, M. P. U., \& Zafar, B. (2020). The impact of COVID-19 on student experiences and expectations: Evidence from a survey (No. w27392). National Bureau of Economic Research. https://doi.org/10.3386/w27392

Azwar, S. (2017). Reliabilitas dan Validitas. Pustaka Belajar.

Barreto, M., Victor, C., Hammond, C,... \& Qualter, P. (2021). Loneliness around the world: Age, gender, and cultural differences in loneliness. Personality and Individual Differences, 169, 1-6. https://doi.org/10.1016/j.paid.2020.1 10066.
Bauer, N. \& Rokach, A. (2012). The Experience of Loneliness in University: A Cross-Cultural Study. International Journal of Adolescence and Youth, 11(4), 283-302. https://doi.org/10.1080/02673843.20 04.9747936

Bek, H. (2017). Understanding the Effect of Loneliness on Academic Participation and Success among International University Students. Journal of Education and Practice. $8(14)$, 46-50. https://doi.org/10.1143922/2222.288

Banerjee, D., \& Rai, M. (2020). Social isolation in Covid-19: The impact of loneliness. International Journal of Social Psychiatry, 66(6), 525-527. https://doi.org/10.1177\%2F0020764 020922269

Beutel, M.E., Klein, E.M., Brähler, E., Reiner, I., Jünger, C., Michal,...Tibubos, A.N. (2017). Loneliness in the general population: prevalence, determinants and relations to mental health. $B M C$ Psychiatry. 17(1), 97-103. https://doi.org/10.1186/s12888-0171262-x.

Borys, S., \& Perlman, D. (1985). Gender Differences in Loneliness. Personality and Social Psychology Buletin. 11(1), 63-74. https://doi.org/10.1177/01461672851 11006

Bu, F., Steptoe, A., \& Fancourt, D. (2020). Loneliness during a strict lockdown: Trajectories and predictors during the 
COVID-19 pandemic in 38,217 United Kingdom adults. Social science \& medicine, 265, 113521. https://doi.org/10.1016/j.socscimed.2 020.113521

Buchholz, E. S., \& Catton, R. (1999). Adolescents' perceptions of aloneness and loneliness. Adolescence, 34(133), 203-213. https://pubmed.ncbi.nlm.nih.gov/102 34378/

de Jong-Gierveld, J. (1987.) Developing and testing a model of loneliness. Journal of Personality and Social Psychology, 53(1), 119-28. https://doi.org/10.1037//00223514.53.1.119.

de Jong-Gierveld, J., Van Tilburg, T., \& Dykstra, P. (2006). Loneliness and Social Isolation. In A. Vangelisti \& D. Perlman (Eds.). The Cambridge Handbook of Personal Relationships (pp. 485-500). https://doi.org/10.1017/CBO978051 1606632.027

de Jong-Gierveld, J., \& Van Tilburg, T. (2006). A 6-item scale for overall, emotional, and social loneliness: Confirmatory tests on survey data. Research on Aging, 28(5), 582- 598. https://doi.org/10.1177/01640275062 89723

Franssen, T., Stijnen, M., Hamers, F. \& Schneider, F. (2020). Age differences in demographic, social and healthrelated factors associated with loneliness across the adult life span (19-65 years): a cross-sectional study in the Netherlands. BMC Public Health, 20, 1118. https://doi.org/10.1186/s12889-02009208-0

Groarke, J., Berry, E., Wisener, L. G., McKenna-Plumley, P., McGlinchey, E., \& Armour, C. (2020). Loneliness in the UK during the COVID-19 pandemic: Cross-sectional results from The COVID-19 Psychological Wellbeing Study. PLoS ONE, 15(9), 1-18.

https://doi.org/10.1371/journal.pone. 0239698

Hawkley, L. C., \& Cacioppo, J. T. (2010). Loneliness matters: A theoretical and empirical review of consequences and mechanisms. Annals of Behavioral Medicine, 40, 218-227. https://doi.org/10.1007/s12160-0109210-8

Heinrich, L. M., \& Gullone, E. (2006). The clinical significance of loneliness: A literature review. Clinical Psychology Review, 26, 695718.

https://doi.org/10.1016/j.cpr.2006.04 .002

Holmes, E. A., O'Connor R. C., Perry, V. H., Tracey, I., Wessely, S., Arseneault, L., Ballard, C., Christensen, H., Cohen Silver R., Everall I, Ford, T., John, A., Kabir, T., King, K., Madan, I., Michie, S., Przybylski, A. K., Shafran, R., Sweeney, A., Worthman, C. M., Yardley, L., Cowan, K., Cope, C., Hotopf, M., \& Bullmore, E. (2020). Loneliness in the general population: prevalence, determinants and relations to mental health. Lancet Psychiatry, 7(6), 547-560. https://doi.org/10.1016/S22150366(20)30168-1.

Holt-Lunstad, J., Smith, T.B., Baker, M., Harris, T., \& Stephenson, D. (2015). Loneliness and social isolation as risk factors for mortality: a meta-analytic review. Perspective Psychology Science. 10(2), 227-37. https://doi.org/10.1177/17456916145 68352 .

Groarke, J.M., Berry, E., GrahamWisener, L., McKenna-Plumley, P.E., McGlinchey, E., \& Armour, C. 
(2020). Loneliness in the UK during the COVID-19 pandemic: Crosssectional results from the COVID-19 Psychological Wellbeing Study. Plos One. 15(9), 1-18. https://doi.org/10.1371/journal.pone. 0239698

Kearns, A. Whitley, E., Tannahill, C. \& Ellaway, A. (2015). 'Lonesome town'? Is loneliness associated with the residential environment, including housing and neighborhood factors?. Journal Community Psychology. 43(7), 849-867. https://doi.org/10.1002/jcop.21711

Kementrian Pendidikan dan Kebudayaan Republik Indonesia (Kemendikbud RI) (2020). Surat Edaran Menteri Pendidikan dan Kebudayaan No. 36962/MPK.A/HK/2020 mengenai Pembelajaran secara Daring dan Bekerja dari Rumah dalam Rangka Pencegahan Penyebaran Corona Virus Disease (COVID-19). https://www.kemdikbud.go.id/main/ blog/2020/03/se-mendikbudpembelajaran-secara-daring-danbekerja-dari-rumah-untukmencegah-penyebaran-covid19

Komite Penanganan Covid-19 dan Pemulihan Ekonomi Nasional. (2021). Data Sebaran. https://covid19.go.id/datasebaran

Li, L.Z., \& Wang, S. (2020). Prevalence and predictors of general psychiatric disorders and loneliness during COVID-19 in the United Kingdom. Psychiatry Research. 291, 113267. https://doi.org/10.1016/j.psychres.20 20.113267

Liu, C. H., Zhang, E., Wong, G. T. F., \& Hyun, S. (2020). Factors associated with depression, anxiety, and PTSD symptomatology during the COVID19 pandemic: Clinical implications for US young adult mental health. Psychiatry Research, 290, 1-7. https://doi.org/10.1016/j.psychres.20 20.113172

Margalit, M. (2010). Lonely Children and Adolescent: Self Perceptions, Social Exclusion, and Hope. Springer Science+Business Media

Ningrumsari, P.R (2018). Hubungan antara regulasi diri dengan kesepian mahasiswa tahun pertama di fakultas kesehatan masyarakat dan fakultas ilmu sosial dan politik Universitas Diponegoro Semarang. Jurnal Empati, 6(4), 37-43 https://ejournal3.undip.ac.id/index.p hp/empati/article/view/19986

Perlman, D., \& Peplau, L.A. (1984). Loneliness research: survey of empirical findings, in: Peplau, L.A. \& Golston, S.E. (Eds). Preventing the Harmful Consequences of Severe and Persistent Loneliness. Government Printing Office.

Pinquart, M., \& Sörensen, S. (2001). Gender Differences in Self-Concept and Psychological Well-Being in Old Age: A Meta-Analysis. The Journals of Gerontology: Series B, 56(4), 195213. https://doi.org/10.1093/geronb/ 56.4.P195

Rubenstein, C.M. \& Shaver, P. (1982) The experience of loneliness. In L. A. Peplau \& D. Perlman. Loneliness: Sourcebook of Current Theory, Research and Therapy (pp. 1-18). Wiley-Interscience.

Sagita, D. D., \& Hermawan, D. (2020). Kesepian Remaja Pada Masa Pandemi COVID-19. ENLIGHTEN: Jurnal Bimbingan Konseling Islam, 3(2), 122-130. https://doi.org/10.32505/enlighten.v3 i 2.1892

Seidel, E. J., Mohlman, J., Basch, C. H., Fera, J., Cosgrove, A., \& Ethan, D. (2020). Journal of Community Health. $\quad 45, \quad 1259-1262$ 
https://doi.org/10.1007/s10900-02000905-w

Shovestul, B., Han, J., Germine, L., \& Dodell-Feder, D. (2020). Risk factors for loneliness: The high relative importance of age versus other factors. PloS One, 15(2), e0229087. https://doi.org/10.1371/journal.pone. 0229087

Son, C., Hegde, S., Smith, A., Wang, X., \& Sasangohar, F. (2020). Effects of COVID-19 on College Students' Mental Health in the United States: Interview Survey Study. Journal of Medical Internet Research. 22(9), e21279.

https://doi.org/10.2196/21279

Stoliker, B.E. \& Lafreniere, K.D. (2015). The Influence of Perceived Stress, Loneliness, and Learning Burnout on University Students' Educational Experience. College Student Journal, 49(1), 146-160. https://eric.ed.gov/?id=EJ1095547

Victor C. R., \& Yang K. (2012). The prevalence of loneliness among adults: a case study of the United
Kingdom. Journal Psychology. 146(1-2), 85-104. https://doi.org/10.1080/00223980.20 11.613875 .

World Health Organization. (2020a). Corona Virus Diasease (COVID-19) Pandemic. https://www.who.int/emergencies/dis eases/novel-coronavirus-2019

World Health Organization. (2020b). Coronavirus Diasease (COVID-19): How is it transmitted? https://www.who.int/emergencies/dis eases/novel-coronavirus-

2019/question-and-answers-hub/q-adetail/coronavirus-disease-covid-19how-is-it-transmitted

Wiseman, H., Guttfreund, D. G., \& Lurie, I. (2007). Gender differences in loneliness and depression of university students seeking counselling. British Journal of Guidance \& Counselling. 2, 231-243. https://doi.org/10.1080/03069889508 253008 